\title{
SHARP TRIANGLE INEQUALITY AND \\ ITS REVERSE IN BANACH SPACES
}

\author{
Mikio Kato, KICHI-SUKe SAITO AND TAKAYUKI TAMURA
}

Abstract. We shall present a sharp triangle inequality and its reverse inequality with $n$ elements in a Banach space $X$, or equivalently we shall estimate the difference $\sum_{j=1}^{n}\left\|x_{j}\right\|-\left\|\sum_{j=1}^{n} x_{j}\right\|$ for given $x_{1}, x_{2}, \ldots, x_{n}$ in $X$, where equality attainedness will be characterized. Several applications will be given.

Mathematics subject classification (2000): 46B20, 46B99.

Key words and phrases: triangle inequality, sharp triangle inequality, reverse triangle inequality, strictly convex Banach space, uniform non- $\ell_{1}^{n}$-ness.

\section{REFERENCES}

[1] B. BeAUZAMY, Introduction to Banach Spaces and Their Geometry, 2nd ed., North-Holland, AmsterdamNew York-Oxford, 1985.

[2] S. S. DRAGOMIR, Reverses of the triangle inequality in Banach spaces, J. Inequal. Pure and Appl. Math., 6, (5) (2005), Art. 129, pp. 46.

[3] C. F. DunKL, K. S. WiLliams, A simple inequality, Amer. Math. Monthly, 71, (1964), 53-54.

[4] H. HudziK, T. R. LANDES, Characteristic of convexity of Köthe function spaces, Math. Ann., 294, (1992), 117-124.

[5] C. JAMES, Uniformly non-square Banach spaces, Ann. of Math., 80, (1964), 542-550.

[6] L. Maligranda, Simple norm inequalities, Amer. Math. Monthly, 113, (2006), 256-260.

[7] J. L. MASSERA, J. J. SCHÄFFER, Linear differential equations and functional analysis I, Ann. of Math., 67, (1958), 517-573.

[8] R. E. MegGinson, An Introduction to Banach Space Theory, Springer, New York, 1998.

[9] D. S. Mitrinović, J. E. PeČARIĆ AND A. M. FinK, Classical and New Inequalities in Analysis, Kluwer Academic Publishers, Dordrecht-Boston-London, 1993.

[10] S. SAITOH, Generalizations of the triangle inequality, J. Inequal. Pure and Appl. Math., 4, (3) (2003), Article 62, pp. 5. 